\title{
Geophysical survey reveals tectonic structures in the Amundsen Sea embayment, West Antarctica
}

\author{
K. Gohl, ${ }^{1}$ D. Teterin, ${ }^{2}$ G. Eagles, ${ }^{1}$ G. Netzeband, ${ }^{3}$ J. W. G. Grobys, ${ }^{1}$ N. Parsiegla, ${ }^{1}$ P. Schlüter, ${ }^{1}$ \\ V. Leinweber, ${ }^{1}$ R. D. Larter, ${ }^{\mathrm{r}}$ G. Uenzelmann-Neben, ${ }^{1}$ and G. B. Udintsev ${ }^{2}$ \\ ${ }^{1}$ Alfred Wegener Institute for Polar and Marine Research, Postbox 120161, 27515 Bremerhaven, Germany (karsten.gohl@awi.de) \\ ${ }^{2}$ Vernadsky Institute of Geochemistry and Analytical Chemistry, Laboratory of Geomorphology and Tectonics of the Ocean Floor, 19 Kosygin St., \\ 117975 Moscow, Russia (d_e teterin@mail.ru) \\ ${ }^{3}$ Institute for Geophysics, University of Hamburg, Bundesstr. 55, 20146 Hamburg, Germany (now at: gnetzeband@ifm-geomar.de) \\ ${ }^{5}$ British Antarctic Survey, High Cross, Madingley Road, Cambridge, CB3 0ET, UK (r.larter@bas.ac.uk)
}

\begin{abstract}
The Amundsen Sea embayment of West Antarctica is in a prominent location for a series of tectonic and magmatic events from Paleozoic to Cenozoic times. Seismic, magnetic and gravity data from the embayment and Pine Island Bay (PIB) reveal the crustal thickness and some tectonic features. The Moho is $24-22 \mathrm{~km}$ deep on the shelf. NESW trending magnetic and gravity anomalies and the thin crust indicate a former rift zone that was active during or in the run-up to breakup between Chatham Rise and West Antarctica before or at $90 \mathrm{Ma}$. NW-SE trending gravity and magnetic anomalies, following a prolongation of Peacock Sound, indicate the extensional southern boundary to the Bellingshausen Plate which was active between 79 and $61 \mathrm{Ma}$.

Citation: Gohl, K., D. Teterin, G. Eagles, G. Netzeband, J. W. G. Grobys, N. Parsiegla, P. Schlüter, V. Leinweber, R. D. Larter, G. UenzelmannNeben, and G. B. Udintsev (2007), Geophysical survey reveals tectonic structures in the Amundsen Sea embayment, West Antarctica, in Antarctica: A Keystone in a Changing World - Online Proceedings of the $10^{\text {th }}$ ISAES, edited by A. K. Cooper and C. R. Raymond et al., USGS Open-File Report 2007-1047, Short Research Paper 047, 4 p.; doi:10.3133/of2007-1047.srp047
\end{abstract}

\section{Introduction}

The Amundsen Sea embayment with its eastern sector, Pine Island Bay (PIB) (Figure 1), is in a tectonically prominent position suggested to be the location of a crustal boundary between the Marie Byrd Land block to the west and the Thurston Island/Ellsworth Land blocks to the east which was active during the Mesozoic break-up of Gondwana or even before (e.g. Dalziel and Elliot, 1982; Storey, 1991; Grunow et al., 1991). Eagles et al. (2004) illustrate that early Pacific-Antarctic separation evolved first as rifting and crustal extension along the present-day Bounty Trough between Chatham Rise and Campbell Plateau (Grobys et al., 2007). It possibly continued along the present Great South Basin between the Campbell Plateau and the South Island of New Zealand at $90 \mathrm{Ma}$ until the rift was abandoned in favour of a new extensional locus to the south, forming the earliest oceanic crust between Campbell Plateau and Marie Byrd Land at 84-83 Ma. The boundary between Chatham Rise and Campbell Plateau - with Bounty Trough closed before $90 \mathrm{Ma}$ - is situated off the western Amundsen Sea Embayment at about $120^{\circ}-125^{\circ} \mathrm{W}$.

The Bellingshausen Plate (Stock and Molnar, 1987) moved independently on the southern flank of the midPacific spreading ridge from Late Cretaceous times until about $61 \mathrm{Ma}$ when a major plate reorganisation occurred in the South Pacific (e.g. Larter et al., 2002; Eagles et al., 2004). The small plate's western boundary was situated in the area of the Marie Byrd Seamounts (Heinemann et al., 1999), its eastern transpressional boundary along a gravity anomaly lineament in the western Bellingshausen Sea. The southern boundary may have been active along the WNW-ESE striking Peacock Gravity Anomaly (PGA) across the outer continental shelf of the Amundsen Sea embayment (Larter et al., 2002; Eagles et al., 2004).
The newest geophysical data from the Amundsen Sea Embayment and PIB (Figure 1) reveal crustal thickness and tectonic features and lineations. These early results are discussed in context with plate-kinematic reconstructions of the early stages of continental breakup and southern Pacific seafloor spreading.

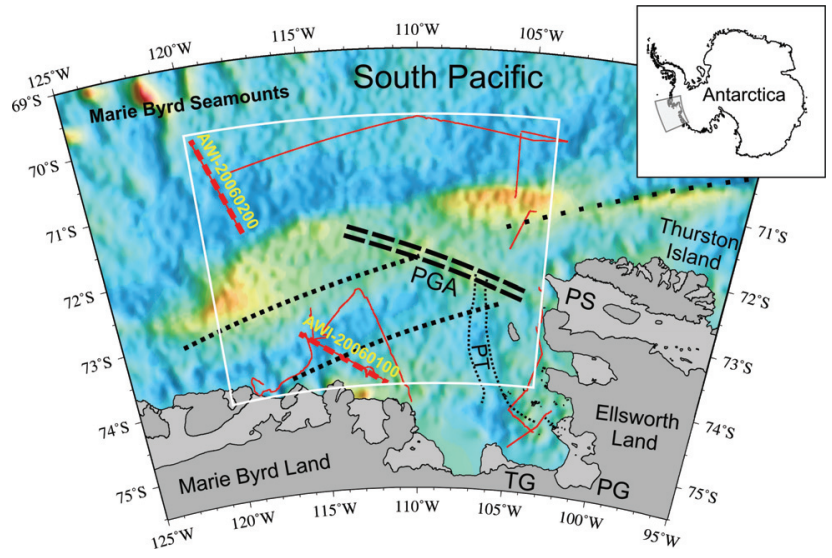

Figure 1. Overview map of the Amundsen Sea embayment and Pine Island Bay showing the satellitederived gravity anomaly grid of McAdoo and Laxon (1997) and the locations of two deep crustal seismic (dashed red lines) and multi-channel seismic profiles (red lines) collected during RV Polarstern expedition ANTXXIII/4. The dotted bold black lines mark the approximate location of the interpreted incipient narrow rift basin. Its trend is aligned with a gravity anomaly north of Thurston Island. The dashed black lines illustrate the presumed location of the southern Bellingshausen Plate boundary. The box marks the area of the Moho depth map of Figure 4. PT Pine Island Through, PGA Peacock Gravity Anomaly, PS Peacock Sound, PG Pine Island Glacier, TG Thwaites Glacier. 
Geophysical data acquisition in the Amundsen Sea Embayment

The Alfred Wegener Institute and British Antarctic Survey cooperated closely during early 2006 with RV Polarstern's expedition ANT-XXIII/4 and RRS James $C$. Ross' cruise JR141. Extensive geophysical datasets were collected as part of a research program dedicated to the study of tectonic, sedimentary and glacial advance/retreat processes in the Amundsen Sea Embayment and PIB (Larter et al., 2007). For this paper, we primarily use the resulting deep crustal seismic profiles, shipborne gravity and magnetic data collected from the Polarstern, and an extensive aeromagnetic survey of $20,000 \mathrm{~km}$ flown by the Polarstern helicopters (Figures 1 and 2). Due to an area of inaccessibility, the magnetic data mainly cover two separate areas: the western Amundsen Sea embayment and the southern and eastern PIB region. The analysis of these data was complemented by the few previouslyexisting seismic and potential field data from the shelf break to the oceanic parts of the Amundsen Sea (Gohl et al., 1997; Nitsche et al., 2000) and by the satellite-derived gravity anomaly field of McAdoo \& Laxon (1997).

We acquired deep crustal seismic wide-angle reflection and refraction data with one profile across the inner to middle continental shelf of the western embayment (AWI-20060100) and another running from the foot of the slope towards the Marie Byrd Seamount cluster of the continental rise (AWI-20060200) (Figure 1). Shots from an airgun cluster, consisting of 8 G.Guns ${ }^{\mathrm{TM}}$ with a total volume of 68 liters $\left(4160 \mathrm{in}^{3}\right)$, fired with 190 bar at a 1-minute interval (150 m nominal spacing), resulted in good quality data with identified phases from the upper to lower crust and the uppermost mantle on both profiles. Restricted by massive pack-ice to the north, west and east and by drifting sea-ice patches, only nine oceanbottom hydrophone $(\mathrm{OBH})$ systems could be deployed at $18-19 \mathrm{~km}$ spacing on the shelf, in order to minimize the risk of instrument loss. Seven OBH systems with the same nominal spacing were deployed along the deep-sea profile. About $2200 \mathrm{~km}$ of multi-channel seismic (MCS) profiles were acquired in the Amundsen Sea Embayment and in PIB using a 600-m long analogue streamer. We also recorded low-fold normal-incidence reflection data from the airgun shots along both OBH profiles with the same streamer. $530 \mathrm{~km}$ of single-channel seismic data were recorded in the embayment during the JR141 cruise (Larter et al., 2007). For this study, we use parts of the MCS dataset to identify the depth of the acoustic basement to constrain thickness and geometries of the sediment cover in the seismic refraction and gravity modelling process. Details of the seismic reflection data with regard to glacial-marine sedimentation processes will be given elsewhere (e.g. Uenzelmann-Neben et al., this volume).

\section{Magnetic grid, seismic and gravity models}

The combined helicopter and shipboard magnetic grid reveals a NE-SW trending system of near-parallel positive magnetic anomaly lineations as the dominant feature in the western embayment (Figure 2). The lineations run parallel to the trend of the satellite-derived gravity anomalies across the middle shelf and that of sharp positive linear gravity anomaly north of Thurston Island. The magnetic grid over the eastern PIB reveals scattered patches of positive and negative anomalies with no significant lineations, except for a the short WNW trend of positive anomalies west of the Peacock Sound. This anomaly lies on top of, and has the same orientation as, the PGA, but it does not follow the PGA farther northwest. However, gravity modeling indicates an elongated body of high-density, possibly magmatic material along the PGA. Some of the scattered magnetic anomalies in the south may be attributed to the numerous igneous and meta-igneous bodies observed in outcrops on islands in PIB and along its eastern mainland shore as observed by the SPRITE Group (1992) and on our Polarstern cruise.

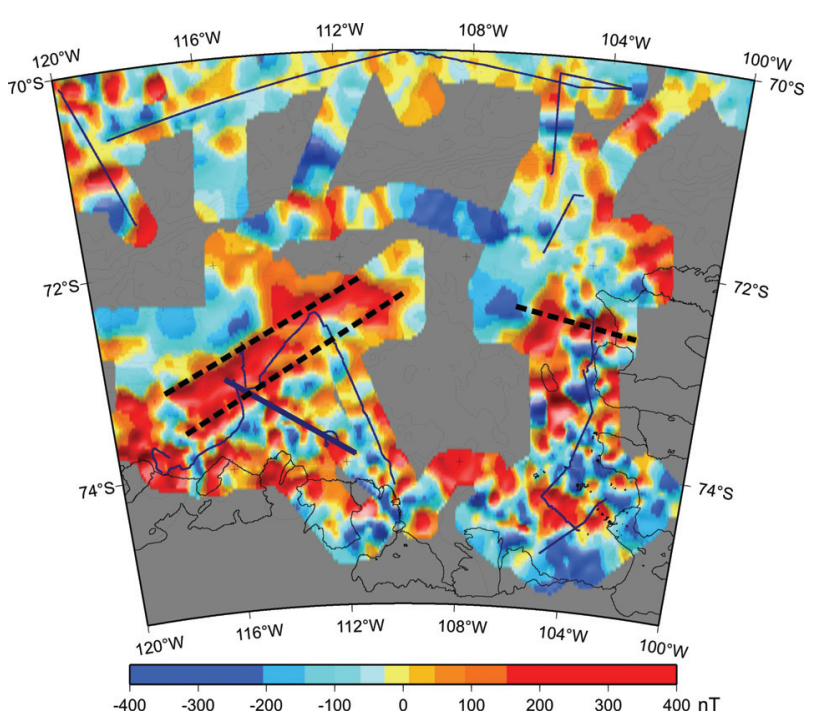

Figure 2. Map of gridded magnetic anomalies in the Amundsen Sea embayment from helicopter-magnetic surveying and ship-board magnetic data of ANT-XXIII/4. Dashed black lines indicate linear anomaly trends. Thin dark blue lines denote seismic reflection profiles of ANTXXIII/4. Thick dark blue lines mark the locations of deep crustal seismic profiles (the southern profile AWI20060100 corresponds to model in Figure 3).

The P-wave phases recorded by eight $\mathrm{OBH}$ systems of shelf profile AWI-20060100 were modeled for a crustal velocity-depth structure using a raytracing and travel-time inversion method. The final velocity-depth model (Figure 3) shows a $22-23 \mathrm{~km}$ thick crust with velocities of $2.0-3.5 \mathrm{~km} / \mathrm{s}$ for the sediments above the acoustic basement, $5.0-6.2 \mathrm{~km} / \mathrm{s}$ for the upper crust below the acoustic basement, and $6.4-6.9 \mathrm{~km} / \mathrm{s}$ for the lower crust. Pn phases indicate an upper mantle velocity of 7.9- 
$8.0 \mathrm{~km} / \mathrm{s}$. The relatively thin crust, the regular vertical velocity distribution, and the average crustal velocity of about $6.4 \mathrm{~km} / \mathrm{s}$, all suggest that the inner continental shelf of the Amundsen Sea embayment rests on stretched continental crust, but is largely unaffected by magmatic intrusions. Unfortunately, the coverage at the northwestern end of the profile does not reach into the area of the linear SW-NE trending magnetic anomalies.

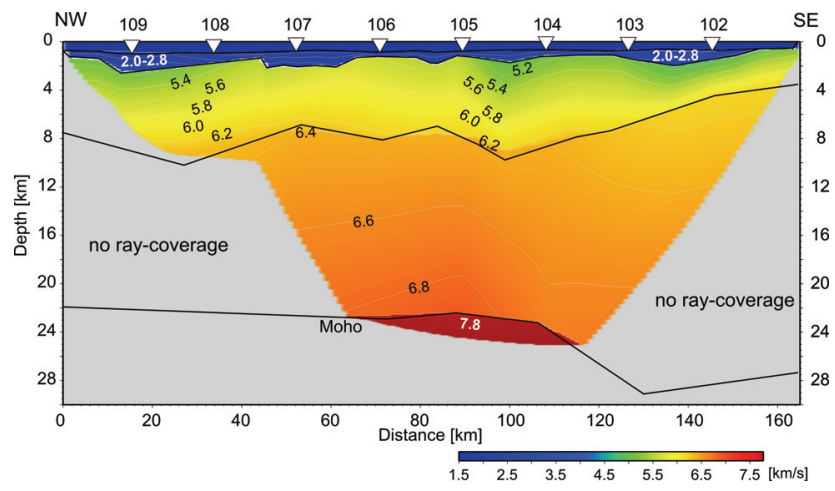

Figure 3. Velocity-depth model of OBH profile AWI20060100 across the inner and middle continental shelf of the western Amundsen Sea embayment. OBH stations are marked by triangles. Layers outside the coloured grid are not constrained by travel-time information but constrained by gravity modelling.

A series of 2-D gravity models were calculated along the seismic and other quasi-linear profiles across the Amundsen Sea embayment primarily using shipboard data complemented by satellite-derived gravity data (McAdoo and Laxon, 1997) in gaps and to extend the profiles. We constrained the models with observations of sediment thickness using seismic reflection data and the crustal structure and thickness from the two $\mathrm{OBH}$ profiles. Next, we integrated the 2-D models into a 3-D gravity anomaly model of the embayment. The resulting map of Moho depth (Figure 4) shows the crust thinning above a Moho at about $24 \mathrm{~km}$ depth beneath the eastern embayment and about $22 \mathrm{~km}$ in the western embayment. Beneath the oceanic crust, the Moho depth increases from $14-15 \mathrm{~km}$ in the east to $15-17 \mathrm{~km}$ in the west between the Marie Byrd Seamounts and the foot of the shelf slope.

\section{Tectonic implications}

The potential field data indicate two dominant and crossing trends of linear anomalies in the Amundsen Sea embayment. The linear gravity and magnetic anomalies of the western Amundsen Sea embayment, running subparallel to each other, can be interpreted as indicating an intrusive crustal origin. Their NE-SW trend parallels the initial spreading center's azimuth between Chatham Rise and West Antarctica and can thus be related to processes occurring during breakup or just beforehand. The anomalously thin crust beneath the inner shelf - in particular of the western embayment - suggests a crustal thinning process. These three observations lead to a model of a failed initial rift or distributed extension in the Amundsen Sea embayment crust. This rift must have been active before $90 \mathrm{Ma}$ or it accompanied the rifting in Bounty Trough and its northward translation of Chatham Rise at this time.

We interpret the WNW trending PGA and its underlying high-density body as a magmatic zone which overprinted the NE-SW trending rift structure. This seems to confirm the suggestion by Eagles et al. (2004) that this zone acted as the southern boundary of the Bellingshausen Plate between 79 and 61 Ma. Platekinematics demonstrates that this plate boundary was active as a zone of relatively minor extensional and translational movements. Our new data show that magmatic intrusions were emplaced in some places along this boundary.

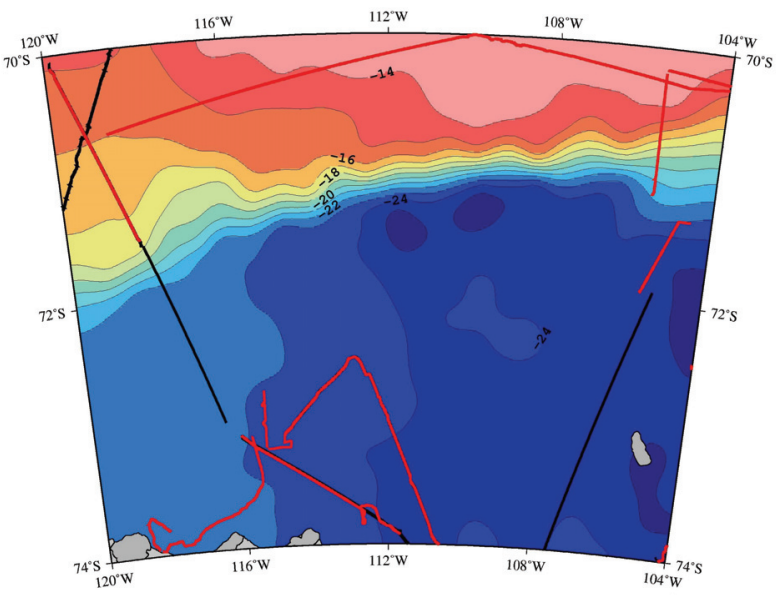

Figure 4. Moho depth map of the Amundsen Sea embayment derived from 2D (along profiles annotated with black lines) and 3D gravity anomaly modeling constrained by satellite-derived gravity data (McAdoo and Laxon, 1997) and seismic data (red lines).

The presumed Paleozoic crustal boundary between the Thurston Island/Ellsworth Land block and the Marie Byrd Land block in PIB is not obvious from the potential field data. If present, the difficulty in interpreting its presence may be traced back to overprinting by Mesozoic and Cenozoic magmatic intrusions and volcanism (e.g. LeMasurier, 1990). What is more, the deeply incised inner and middle shelf of PIB with glacial troughs and channels reaching 1000-1500 $\mathrm{m}$ depth (Lowe and Anderson, 2002; Larter et al., 2007) may obscure interpretations of the magnetic anomaly field. We agree with an earlier suggestion by the SPRITE Group (1992) that the main deep glacial erosional trough, here named Pine Island Trough (Figure 1), stretching from the mouth of the Pine Island Glacier to the middle shelf in NW and 
NNW orientation may have exploited such a former crustal block boundary.

\section{Conclusions}

Seismic, magnetic and gravity surveying of the Amundsen Sea embayment and PIB reveal important phases of the tectonic evolution in this area. The main results are:

(1) The Moho depth of the inner and middle shelf is between 24 and $22 \mathrm{~km}$ and thins from east to west.

(2) Dominant NE-SW trending magnetic and gravity anomalies and the thin crust indicate a former rift zone proposed to be active during or prior to the breakup between Chatham Rise and West Antarctica before or at $90 \mathrm{Ma}$.

(3) NW-SE trending gravity and short magnetic anomalies in the prolongation of the Peacock Sound are consistent with the proposed tectonic activity and location of the southern Bellingshausen Plate boundary between 79 and $61 \mathrm{Ma}$.

(4) A presumed crustal block boundary between Thurston Island/Ellsworth Land block and the Marie Byrd Land block cannot be clearly observed in PIB. It is possible, however, that the glacial Pine Island Trough exploited such a former crustal block boundary or inherited structure.

Acknowledgments. We gratefully acknowledge the excellent support of Captain Uwe Pahl and his officers and crew of RV Polarstern during expedition ANT-XXIII/4. We thank Ernst Flüh of IfM-GEOMAR for lending us four $\mathrm{OBH}$ systems. Many thanks go to Ian Dalziel and Michael Studinger for very helpful reviews and to the co-editor Bryan Storey for the editorial work.

\section{References}

Dalziel, I.W.D., and D. H. Elliot (1982), West Antarctica: problem child of Gondwanaland, Tectonics, 1, 3-19.

Eagles, G., K. Gohl, and R. B. Larter (2004), High resolution animated tectonic reconstruction of the South Pacific and West Antarctic margin; Geochemistry, Geophysics, Geosystems $\left(\mathrm{G}^{3}\right), \quad 5$, doi:10.1029/2003GC000657.

Gohl, K., F. Nitsche, K. Vanneste, H. Miller, N. Fechner, L. Oszko, C. Hübscher, E. Weigelt, and A. Lambrecht (1997), Tectonic and sedimentary architecture of the Bellingshausen and Amundsen Sea Basins, SE Pacific, by seismic profiling, in The Antarctic Region: Geological Evolution and Processes, edited by C. A. Ricci, pp. 719723, Terra Antartica Publication, Siena.
Grobys, J. W. G., K. Gohl, B. Davy, G. Uenzelmann-Neben, T. Deen, and D. Barker (2007), Is the Bounty Trough, off eastern New Zealand, an aborted rift?, J. Geophys. Res., 112, B03103, doi: $10.1029 / 2005 J B 004229$.

Grunow, A. M., D. V. Kent, and I. W. D. Dalziel (1991), New paleomagnetic data from Thurston Island: Implications for the tectonics of West Antarctica and Weddell Sea opening, J. Geophys. Res, 96, B11, 17935-17954.

Heinemann, J., J. Stock, K. Clayton, S. Hafner, S. Cande, and C. Raymond (1999), Constraints on the proposed Marie Byrd LandBellingshausen plate boundary from seismic reflection data, J. Geophys. Res., 104, 25321-25330.

Larter, R. D., A. P. Cunningham, P. F. Barker, K. Gohl, and F. O. Nitsche (2002), Tectonic evolution of the Pacific margin of Antarctica - 1. Late Cretaceous tectonic reconstructions, J. Geoph. Res., 107(B12), 2345, doi:10.1029/2000JB000052.

Larter, R.D., K. Gohl, C. D. Hillenbrand, G. Kuhn, T. J. Deen, R. Dietrich, G. Eagles, J. S. Johnson, R. A. Livermore, F. O. Nitsche, C. J. Pudsey, H.-W. Schenke, J. A. Smith, G. Udintsev, and G. Uenzelmann-Neben (2007), West Antarctic Ice Sheet change since the last glacial period, EOS Trans., Am. Geophys. Union, 88, 189-196.

LeMasurier, W. E. (1990), Late Cenozoic volcanism on the Antarctic plate: an overview, in Volcanoes of the Antarctic Plate and Southern Oceans, edited by W. E. LeMasurier and J. W. Thomson, Am. Geophys. Union Antarct. Res. Ser., 48, pp. 1-19.

Lowe, A. L., and J. B. Anderson (2000), Reconstruction of the West Antarctic ice sheet in Pine Island Bay during the Last Glacial Maximum and its subsequent retreat history, Quat. Sci. Reviews, 21, 1879-1897.

McAdoo, D.C., and S. Laxon (1997), Antarctic tectonics: Constraints from an ERS-1 satellite marine gravity field, Science, 276, 556-560.

Nitsche, F. O., A. P. Cunningham, R. D. Larter, and K. Gohl (2000), Geometry and development of glacial continental margin depositional systems in the Bellingshausen Sea, Marine Geology, 162, 277-302.

SPRITE Group (1992), The southern rim of the Pacific Ocean: Preliminary geologic report of the Amundsen Sea - Bellingshausen Sea cruise of the Polar Sea, 12 February - 21 March 1992, Ant. J. of the U.S., 27, 11-14.

Stock, J., and P. M. Molnar (1987), Revised history of early Tertiary plate motion in the south-west Pacific, Nature, 325, 495-499.

Storey, B. C. (1991), The crustal blocks of West Antarctica within Gondwana: reconstruction and break-up model, in Geological Evolution of Antarctica, edited by M. R. A. Thomson, J. A. Crane, and J. W. Thomson, Cambridge Univ. Press, Cambridge.

Uenzelmann-Neben, G., K. Gohl, R. D. Larter, and P. Schlüter (this volume), Differences in ice retreat across Pine Island Bay, West Antarctica, since the Last Glacial Maximum: indications from multichannel seismic reflection data, in Antarctica: A Keystone in a Changing World - Online Proceedings of the $10^{\text {th }}$ ISAES, edited by A. K. Cooper and C. R. Raymond et al., USGS Open-File Report. 